\title{
The essence of thermovision research in the prevention of fires in underground workings
}

\author{
Marta Stempniak ${ }^{1 *}$ \\ ${ }^{1}$ Faculty of the Geoengineering, Mining and Geology, Wroclaw's University of Science and \\ Technology, ul. Na Grobli 15, 50-421 Wrocław, Poland
}

\begin{abstract}
Underground fires are phenomena that pose a possibly fatal threat to human life, and they are particulary dangerous in the environment of underground workings where the amount of space and number possible escape routes are limited. Therefore, it is important to carefully control changes in temperature and the condition of machinery and equipment used in mine in order to avoid critical situations. The most common cause of fires are defects in mechanical and electrical devices, in order to conduct an analysis of their condition thermal imaging is perfectly suitable. In this article approximed a problem of underground fires, thermal imaging diagnostic method, temperature measurements taken in the KWK ROW Ruch Chwałowice in Rybnik, made an analysis of publicly available data from the KGHM mines and methods of combating the factors leading to the fire emergency been proposed.
\end{abstract}

\section{Introduction}

Underground mining plays a very important role in industry in the world, today's reality and its technologies cannot do without copper and despite significant changes for the sake of environment protection, hard coal remains one of the basic energy sources and a strategic resource for many countries. Mining activities are associated with the occurrence of threats, such as presence of methane, dust, and spontaneous combustion of coal. These affect the safety of employees and the continuity of mining operation. Exceeding the allowable amount of gas in mine air, established by Polish regulations prevents mining, in which case it is necessary to disconnect the power supply - electricity [1-2].

Nowadays it is possible to observe ongoing research on combating natural hazards $[7,8]$. In the works on innovative technologies [3] significant conclusions were shown regarding the increase of work safety in underground mining $[4,5,6,7]$. Due to the high risk posed by the occurrence of fires in mining excavations it is necessary to regularly analyze the term conditions of devices which are the most common cause of fire hazard formation. The temperature measurements described in this paper are further elaborated on in [6], while the data that has been analyzed for the copper mine can be found $[5,8]$. The purpose of this consideration was to describe the conditions in which dangerous situations occur, critical temperatures of devices, favorable conditions - the composition of the mine air and its flow. The focus was on methods of preventing these phenomena and quick

\footnotetext{
${ }^{*}$ Corresponding author: marta.stempniak5@wp.pl
} 
reactions that will support the use of thermal vision. The temperature distribution presented in the thermographic photos is an invaluable help in analyzing and rescue operations in an atmosphere of significant dusting.

\section{Fires in mines}

According to the Ordinance of the Minister of Economy, the definition of 28 June 2002, § $370 \mathrm{sec} .1$ on occupational health and safety, operation and specialized fire protection in underground mining plants, a fire in mining is defined as the occurrence of open fire, being a burning or openly incandescent substance as well as smoke in the mining air or flowing air with carbon monoxide concentration above $0.0026 \%$ [5]. There are two types of fires: exogenous and endogenous. They are caused by the appearance of heat source - external or resulting from physicochemical changes [4]. Underground fires are classified as technical hazards. During the incident fire, poisonous gases and smoke spread quickly and therefore pose a threat over long distances to a significant number of workers [8]. In a situation where mining is carried out in zones particularly endangered by the emission of the mine ventilation plays an important role. The conditions for self-ignition are created by the migration of the gas mixture in the gasps crevices, this may lead to their thermal activation, which results in the emission of fumes and the formation of an open fire [2, 7].

\section{Applications of thermovision in underground mines}

Conducting research with the use of thermal imaging cameras is carried out in a nondestructive manner, because they are performed without the need to stop the work or shut down devices or other installations. Testing with a thermal imaging camera is based on measuring the temperature from the outer surface, the temperature distribution is composite. In order to obtain the appropriate values, the average is determined which is the basis for conclusions. The non-contact measurement method, being the tomographic measurements, is particularly important in research, control and rescue operations, the industry being just one of the applications. In order to obtain reliable measurements results, it is important to determine the emissivity of the tested elements. The higher the emissivity of the tested object, the more heat it emits $[9,6,11]$.

Due to the possibilities of using thermal imaging cameras in underground workings, their use over the years has contributed to the improvement of safety in mining plants, taking into account a number of natural hazard occuring in this industry branch. In underground mines, thermal imaging cameras are used primarily by maintance services that monitor the condition of devices. They are also used by mine rescuers during rescue operations $[6,12]$. 


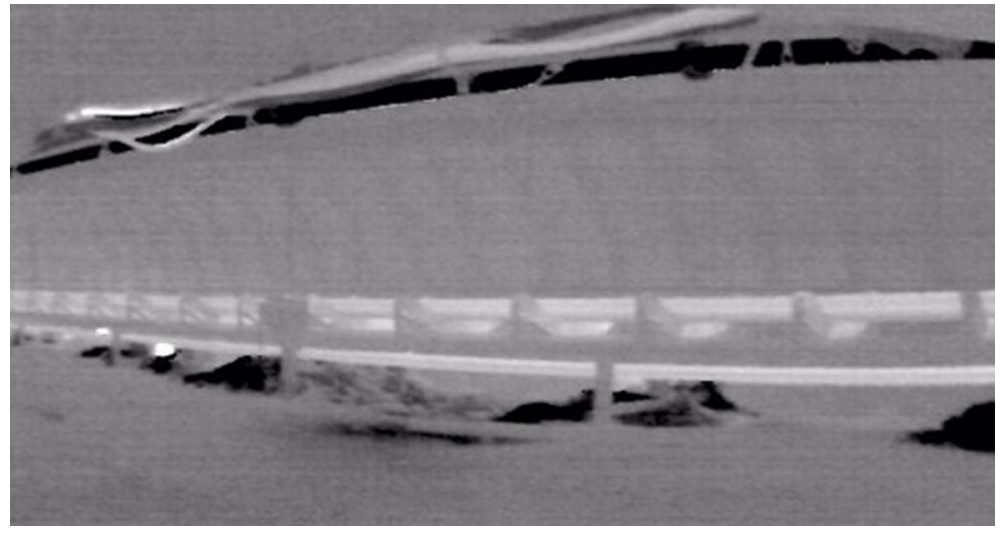

Fig. 1. Belt conveyor TP-2 around the excavation.

In the research in KWK ROW Ruch Chwałowice thermal cameras Dräger UCF $9000 \mathrm{i}$ FLIR i60 were used. Those two types are approved for use in underground mine conditions.
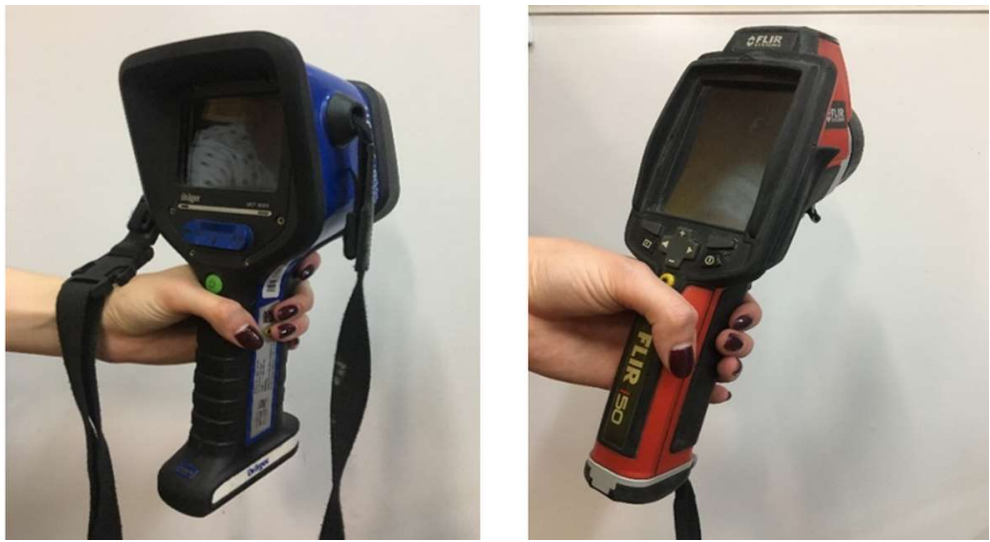

Fig. 2. Thermal cameras used in KWK ROW Ruch Chwałowice.

Thermal imagers work in several modes: thermal scan (locating hot spots); fire (fire fighting); persons (for search and rescue operations); Scan PLUS (seach for heat sourcesreal image); hazardous substances (leak detection and determination of leakage levels allowing the identification of various hazards) [6].

\section{Measurements taken in a hard coal mine}

Belt conveyors are the main method of transporting spoil in hard coal mines. Unfortunately, they are often the cause of the underground fires, more precisely the defects that appear during operation. The main causes of fires involving conveyors are belt friction, seizure of drive elements, fire of flammable liquids, belt slippage against the drive elements, brake frictions or overheating of the conveyor gear. Any increase in material transfer resistance results in an increase in the operation of the engine and gears in the drive system and thus temperature of these elements increases which may result in a fire. $[6,12]$

Analyzed measurements photos were taken in KWK ROW Ruch Chwałowice on the main haulage conveyor. The drive units in thermal images were tested during morning shift in order to obtain reliable results. 

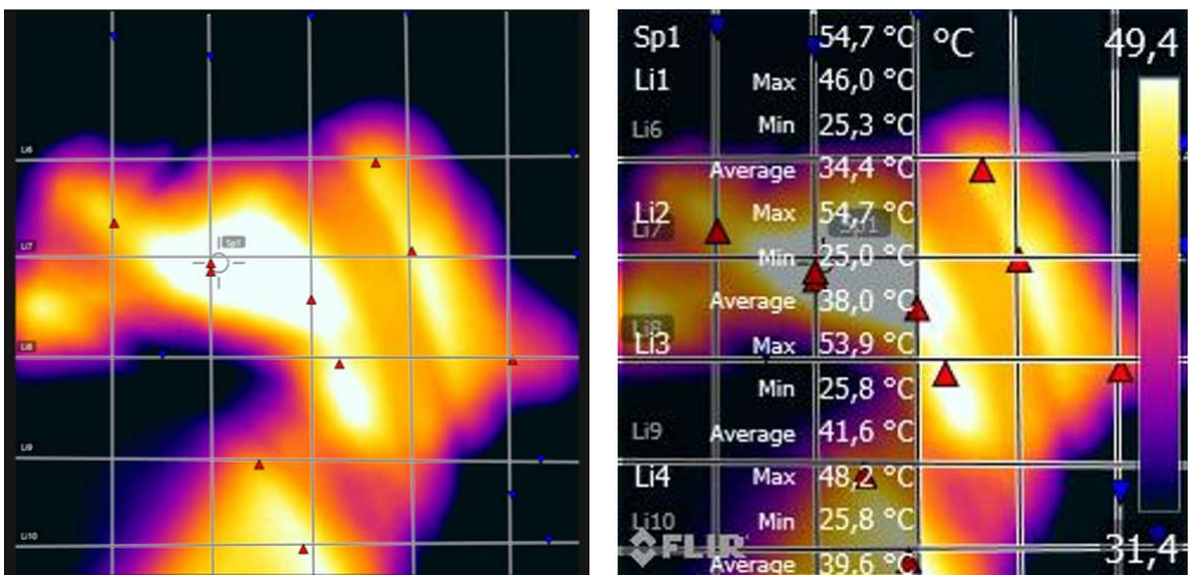

Fig. 3. Temperature distribution of the gear, measurements taken with FLIR i60, developed using FLIR Tools program.

More information about the research of the thermal condition of the belt conveyor's drive unit in the mentioned mine can be found in the works [6].
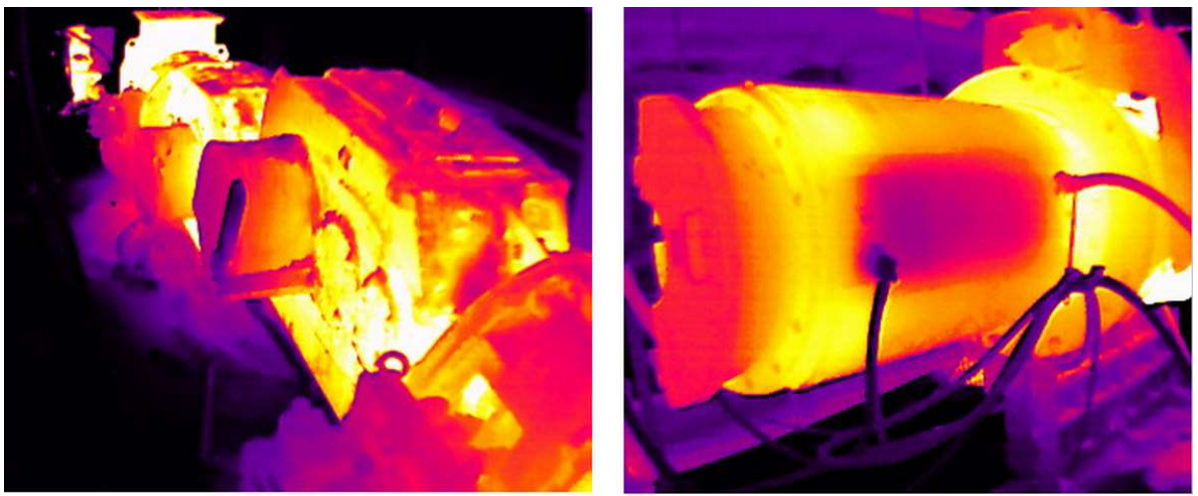

Fig. 4. Temperature distribut of the gear and engine of belt conveyor's drive unit TP II PIOMA 1400, thermal images were taken with Dräger UFC 9000.

\section{Analysis of data obtained in KWK ROW Ruch Chwałowice}

The collected data was analyzed in terms of the temperature distribution in the drive systems of belt conveyors, the failures of which contribute to the emergence of fire hazards and other dangerous failures. The main aim of the research was to detect the critical temperature of $60{ }^{\circ} \mathrm{C}$ or the risk of its occurrence. In the case of belt conveyors that were tested, no alarming occurrences of temperatures reaching or exceeding $60{ }^{\circ} \mathrm{C}$ were noticed. The research shows that use of thermographic methods is useful in the diagnostics of mining machines and devices in order to avoid fire hazards in the mine. The above thermal images (figures 3 and 4) show in detail the temperature distribution on the tested objects, in this case for the TP II PIOMA 1400 belt conveyor's drive unit system. On this basis, it is clear that the way in which every difference in temperature is visually highlighted in the thermal imaging photos allows to detect changes in the technical condition of each device 
and element, such as belt conveyor's elements, which will allow the security services to efficiently control and contribute to the prevention of fires underground. The threats posed by high temperatures and leaks in systems in coal mines are all the more dangerous due to coal dust and methane present in the mine air.

\section{Analysis data from KGHM mines}

On the basis of the publicly available information, the fire hazard in copper ore mines is caused by dangerous climatic conditions resulting from the temperature of the depth at which the works are carried out. Additional heat emission comes from operating machines, which has an impact on the safety of miners' work and the operation of devices [5]. In the mining plants of KGHM Polska Miedź SA, self-propelled mining machines are used, responsible for drilling, bolting, loading holes with explosives and hauling away the excavated material. Key items to pay attention to are electrical cabinet, electric cable reels and the diesel engine. Due to their structure and the content of flammable materials, such as diesel and hydraulic oils, they must be equipped with permanent fire-extinguishing systems and additionally handheld fire-fighting equipment. [3, 5, 9].

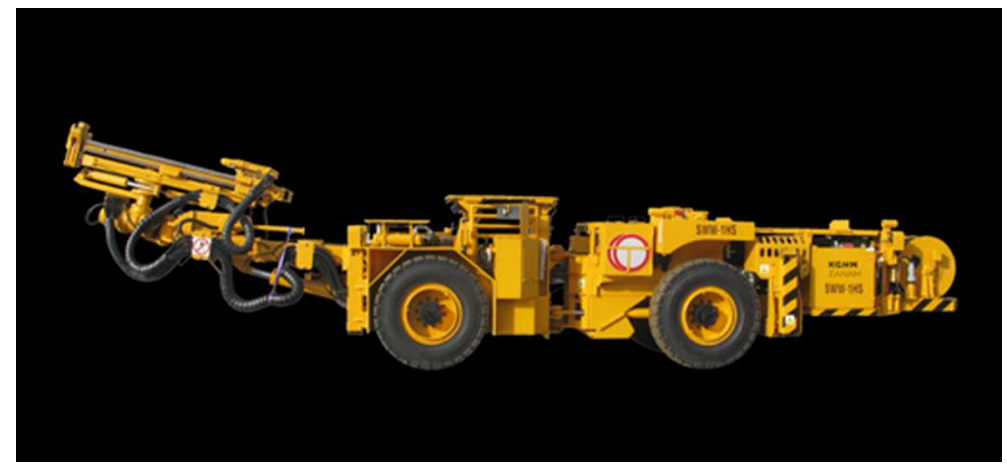

Fig. 5. Self-propelled drilling car KGHM [11].

In copper ore mines, unlike in hard coal mines, there is no risk of endogenous fires because copper ores are not flammable. One of the most common causes of fires in these mines are: inadequately operated, damaged or malfunctioning mechanical devices and machines, ignitation of the belt conveyor belt as a results of friction against the metal structure and defective workmanship or damage to power equipment and installations. In special-purpose vehicles and for passenger transport, there are detailed guidelines regarding the material from which the elements should be made and their distribution in order to prevent the contact of flammable substances with electric wires in the event of failure [5]. 


\begin{tabular}{|c|c|c|c|}
\hline Lp. & Date of the incident & Name of the mining plant & $\begin{array}{l}\text { The place where the event } \\
\text { occurred }\end{array}$ \\
\hline 1. & 16.04 .2008 & O/ZG "Lubin" & Tank \\
\hline 2. & 18.11 .2008 & O/ZG "Polkowice-Sieroszewice" & $\begin{array}{l}\text { Self-propelled mining } \\
\text { machine }\end{array}$ \\
\hline 3. & 24.12 .2008 & O/ZG "Polkowice-Sieroszewice" & $\begin{array}{l}\text { Self-propelled mining } \\
\text { machine }\end{array}$ \\
\hline 4. & 06.04 .2009 & O/ZG "Polkowice-Sieroszewice" & $\begin{array}{l}\text { Self-propelled mining } \\
\text { machine }\end{array}$ \\
\hline 5. & 30.04 .2009 & O/ZG "Polkowice-Sieroszewice" & $\begin{array}{c}\text { Self-propelled mining } \\
\text { machine }\end{array}$ \\
\hline 6. & 07.11 .2009 & O/ZG "Rudna" & $\begin{array}{l}\text { Self-propelled mining } \\
\text { machine }\end{array}$ \\
\hline 7. & 22.01 .2010 & O/ZG "Lubin" & $\begin{array}{c}\text { Self-propelled mining } \\
\text { machine }\end{array}$ \\
\hline 8. & 20.07 .2010 & O/ZG "Rudna" & Portable fuel compressor \\
\hline 9. & 22.07 .2010 & O/ZG "Polkowice-Sieroszewice" & Belt conveyors \\
\hline 10. & 17.04 .2012 & O/ZG "Polkowice-Sieroszewice" & $\begin{array}{l}\text { Self-propelled mining } \\
\text { machine }\end{array}$ \\
\hline 11. & 26.01 .2013 & O/ZG "Polkowice-Sieroszewice" & Blast miner's chamber \\
\hline 12. & 09.02 .2013 & O/ZG "Polkowice-Sieroszewice" & $\begin{array}{c}\text { Self-propelled mining } \\
\text { machine }\end{array}$ \\
\hline 13. & 15.07 .2013 & O/ZG "Rudna" & $\begin{array}{c}\text { Self-propelled mining } \\
\text { machine }\end{array}$ \\
\hline 14. & 21.09 .2013 & O/ZG "Polkowice-Sieroszewice" & Belt conveyors \\
\hline 15. & 03.04 .2014 & O/ZG "Polkowice-Sieroszewice" & $\begin{array}{l}\text { Self-propelled mining } \\
\text { machine }\end{array}$ \\
\hline
\end{tabular}

Fig. 6. Translated data from [3].

In the figure above you can see the causes of exogenous fires in copper mines. Technological problems that occurred in the indicated machines and places, described in [3] most of the fires were caused by the contact of the leaking hydraulic or diesel oil and its contact with a source of high heat. Leak detection is possible with the use of thermal imaging cameras thanks to the modes mentioned earlier. A frequent cause of fires were also an electrical short circuits which led to the ignition of rubber elements in self-propelled machines. This shows how dangerous are any possible minor faults that could be prevented by an appropriate inspection. In the summary of the analyzed research [5] it was stated that constant diagnostic monitoring will allow to reduce the failure rate machines.

\section{Conclusion}

On the basis of the conducted research, the usefulness of using thermographic methods in the diagnostics of machines and devices in order to avoid fire hazards in the mine can be noticed. The above thermal images show in detail the temperature distribution on the tested objects. The use of thermovision allowed for efficient and quick control of the thermal condition of the drive systems in a non-contact manner, which additionally increased the reliability of the obtained results and the safety of the test. The ability to see how the temperature spreads on the tested objects, locating leaks and damage significantly supports the inspection of the condition of mining machinery and equipment, which allows you to minimize the risk of fire in underground mines. Regular checks of the condition of drive systems, fuel connections and elements where there is a risk of increased friction will significantly increase the safety of underground mining plants. Research will be continued in the future. 


\section{References}

1. W. Malicki, B. Miedziński, Mechanizacja i Automatyzacja Górnictwa, 7(461), 34-38, (2009)

2. M. Tutak, J. Brodny, D. Szurgacz, L. Sobik, S. Zhironkin, Energies, 13(18), 4891 (2020)

3. J. Wodecki, M. Góralczyk, P. Krot, B. Ziętek, J. Szrek, M. Worsa-Kozak, R. Zimroz, P. Śliwiński, A. Czajkowski, Energies, 13, 6748 (2020)

4. A. Grodzicka, Górnictwo i geologia, 7(3), 1 (2012)

5. T. Sawicki, Pożary samojezdnych maszyn górniczych (Przegląd Pożarniczy, 2016)

6. M. Stempniak, V. Zhironkin, A. Epikhin, K. Trzop, D. Szurgacz, IOP Conf. Ser.: Earth Environ. Sci. 684012010 (2021)

7. D. Szurgacz, M. Tutak, J. Brodny, L. Sobik, O. Zhironkina, Energies, 13(17), 4538 (2020)

8. P. Jasiński, P. Jasiński, S. Janik, CUPRUM-Czasopismo Naukowo-Techniczne Górnictwa Rud, 4(77), 97-107 (2015)

9. D. Żabicki, Elektroinstalator, 3, 48-51, (2016)

10. Grupa Kapitałowa KGHM Polska Miedź S.A. URL: https://www.kghmzanam.com/produkty/maszyny-gornicze/wozy-wiercacokotwiace/sww-1hs-rrw/

11. A. Broja, J. Mróz, Instytut Technik Innowacyjnych EMAG, 6, 496, (2012) 